\title{
Promoting Collaboration in Jabodetabekjur: A Learning Regions Perspective on Knowledge-Based Economy
}

\author{
Muhammad Rahmat Yananda ${ }^{1}$ \\ Irfan Ridwan Maksum² \\ Heri Fathurahman ${ }^{3}$
}

\begin{abstract}
This research raised issues on knowledge - based economy (KBE) in Jabodetabekjur, especially Bogor, Depok and South Tangerang. Using qualitative approach, this research examines collaboration involving city governments, college/research institutions, businesses/industries, communities and found the reasons why collaborations for the benefit of KBE in Jabodetabekjur as a learning region has not established yet. The causes are: (1) lack of cohesion in terms of policy/ administration, ecology, economics and social system; (2) institutional failure; (3) non optimal regional cooperation; (4) unalignment with the national urban development strategies; and (5) loss of momentum in KBE development. Learning regions can be constructed by analyzing a path or trajectories combined with the potentials of the urban region elements (Academicians, Businesses, Communities and Governments). They can also be constructed via governance approach and development of appropriate organizational models. City's administrations should take active roles as the initiator of the collaboration process opted by certain types and activities. Strategy and policy - making related to collaboration gave rise to: (1) KBE development themes; (2) vision/ mission statements; and (3) principles of engagement and capacities. Resources gaps were found and can be applied as inputs to build joint projects, namely: (1) incubation and innovation centers; and (2) product innovation promotion center.
\end{abstract}

\section{Keywords:}

learning regions; knowledge-based economy (KBE); new regionalism; governance; collaboration.

\begin{abstract}
Abstrak
Penelitian ini mengangkat isu yang terkait dengan ekonomi berbasis pengetahuan (KBE) di region perkotaan Jabodetabekjur, khususnya kota Bogor, Depok and Tangerang Selatan. Menggunakan pendekatan kualitatif, penelitian ini menelaah kolaborasi antara pemerintah kota, institusi pendidikan atau penelitian, bisnis atau industri dan komunitas. Penelitian ini menemukan alasan mengapa kolaborasi untuk membangun Jabodetabekjur sebagai learning region dalam konteks ekonomi berbasis pengetahuan belum terjadi. Penyebabnya adalah: (1) ketiadaan kohesi dalam hal kebijakan/administrasi, ekologi, ekonomi maupun sosial; (2) kegagalan institusional; (3) kurang optimalnya kerjasama regional; (3) kekurangselarasan dengan strategi nasional pembangunan perkotaan; and (4) kehilangan momentum terkait perkembangan $K B E$. Learning regions dapat dibangun dengan menganalisis gabungan antara jalur atau trajectories dengan potensi elemen region perkotaan, baik itu kampus atau lembaga penelitian, bisnis, komunitas dan pemerintah. Learning regions juga dapat dibangun melalui pendekatan pemerintah dan pembangunan model organisasi yang sesuai. Pemerintah kota harus mengambil peran aktif sebagai inisiator proses
\end{abstract}

\footnotetext{
${ }^{1}$ Administration Science Department, University of Indonesia.

Email: rahmatyananda@yahoo.com

2 Administration Science Department, University of Indonesia.

${ }^{3}$ Administration Science Department, University of Indonesia.
} 
kolaborasi tergantung jenis dan aktivitas yang dilakukan. Strategi dan pembuatan kebijakan terkait kolaborasi membuka jalan untuk: (1) tema untuk pembangunan KBE; (2) penyataan visi dan misi; (3) prinsip - prinsip terkait pelibatan dan kapasitas. Temuan lainnya adalah perbedaan sumber daya yang dapat diterapkan sebagai input untuk membangun proyek bersama seperti: (1) pusat inkubasi dan inovasi; dan (2) pusat promosi produk inovasi.

\section{Kata Kunci:}

learning regions; ekonomi berbasis pengetahuan (KBE); regionalisme baru; governance; kolaborasi.

\section{Introduction}

The rise of urban regions in Indonesia increasingly urged the development of knowledge - based economy (KBE). Urban regions became the locus of $\mathrm{KBE}$ because they have significant supporting infrastructures (Porter, 1990; Van den Berg and Van Winden, 2004; OECD, 2005a; OECD, 2005b; Porter, 2007; Van Winden et al, 2010; Carvalho, 2013). Richard Florida, an urban studies theorist and expert who promotes knowledge-based economy, coined this trend as learning regions (in Rutten and Boekema, 2007: 64-66) with Silicon Valley, which has a long history - based $\mathrm{KBE}$, as a classic example of the success of learning regions.

Urban infrastructure is a precondition of KBE since cities need to promote themselves as learning regions to invite, bring and build creative workers. Therefore, city and urban region require learning infrastructure regions (OECD, 2001; OECD, 2007; Gustavsen et al., 2007; OECD, 2013) that are connected to facilitate the flow of knowledge, ideas and learning. Region is a place that has the basic elements in forming the system of production, i.e. manufacturing infrastructure, human, physical and communication and industrial implementation.

Learning region promotion as a form of economic urban development also requires collaboration between three (3) main actors in the triple helix (Etkowitz 2008; Purwaningrum, 2012), i.e. public and private universities and or research institutions, businesses and national as well as local government (Rainey,
Hal G, 2009: 79). Triple helix is a way to build regional economies by means of knowledge production and collaboration (Cooke and Leydesdorff, 2006; Etzkowitz and Leydesdorff, 2000; Supriyadi, 2012; Martini et al., 2013). Triple helix can be expanded into quadruple helix by adding "media culture and culture based public" as well as "civil society" as the fourth element (Carayannis and Campbell, 2012 :13), or community (Kolehmainen, et.al, 2015), especially for lagging regions.

In Asia, apart from Japan, South Korea became the classic example of economic growth using KBE technology and innovation (World Bank, 1999: 1; Suh and Chen, 2007), thanks to a long history of spatial planning/industrial development of city/urban region (OECD, 2007: 242-250). In Indonesia KBE is still an ongoing concern and deserved unfavorable tone in OECD report. However, some regional reports allowed flourishing hopes (Hudalah and Word, 2012; Irawati and Rutten, 2011).

The locus of this research, i.e. Bogor, Depok and South Tangerang has potentials to become learning regions based on the path of urban development, development planning, $\mathrm{KBE}$, supporting and $\mathrm{R} \& \mathrm{D}$ infrastructures. Bogor has a trajectory of research and science since Bogor Botanical Gardens was built hundred of years ago. The path was enforced with Bogor Agricultural Institute (IPB) and its supporting institutions such as Bogor Life Science and Technology. Depok is the locus of University of Indonesia (UI) and right now is a home of business startups and co - working spaces. Meanwhile South Tangerang has been 
the site of Center of Science and Technology (Puspiptek) and technological - based products manufacturers. These three cities have more adequate infrastructures as their advantages for promoting KBE, especially with the presence of university/public research institutions.

The implementation of learning regions in all three (3) cities will have a better chance if done collectively or by collaborating. Each city has its advantages and disadvantages as a pre learning region since Jabodetabekjur is the largest urban region in Indonesia. Its success will be an encouraging example and will help boosting the performance of $\mathrm{KBE}$ since the country will have some 135 million middle-class market in 2030 (ADB, 2014: 60). And according to Act No. 17/2007 on the National Development Plan (RPJN) 2005 2025 and Master Plan for the Acceleration and Expansion of Indonesian Economic Development 2011 - 2025 (MP3EI) Indonesia will focus on strengthening the capacity of human resources s well as science and technology in learning regions nationwide.

This study was aimed to answer: (1) why learning regions did not manifest in Jabodetabekjur urban region?; (2) how to build Jabodetabekjur urban learning regions, particularly in Bogor, Depok and South Tangerang?; and (3) what kind of collaboration concerning the three cities in relations with three (3) types of strategic goals (policy/ strategy making, resource exchange, and project based) with actors in developing learning regions?

\section{Cities with KBE}

The third wave of economic development raised issues about regional collaboration and focused on how regional resources support the growth of groups of companies and not just a single one. The network allowed technology, human resources and capital to work in a closely knit together in order to gain competition globally (Blakely and Bradshaw,
2002: 45-46). Regional collaboration was needed in developing regional economics. Therefore the government ideally chose collaboration to make sure its regional economic development works. Collaborative approach in the urban region administration can be traced to $\mathrm{New}$ Regionalism school of thought. As one out of four (4) basic system of regional governance, i.e consolidation, many levels, and regional special districts (Hamilton, 2013: 4-6), New Regionalism with its collaborative approach can be considered as a solution to the fragmentation of public administration (Kubler, 2012). Learning regions is one of collaboration manifestation. The concept underlies learning regions are described below.

\section{KBE Actors: The Triple Helix}

Triple Helix is a platform for the creation of "institutional formation", a new organizational format that promotes innovation. Relationships among universities, industries and governments are reciprocal where each element works to improve the performance of others in a regional context or in the industrial clusters. Triple and quadruple helix has changed course, making the production of knowledge and new technologies are more important than ever (Etzkowitz, 2008: 8). The path to triple helix originated from two (2) opposing positions: (1) the static model in which the government controls the universities and industries; and (2) the laissez-faire model in which universities, industries and the government are separate entities and each perform simple and cross - border interactions. The third model is intertwined in the third helix (Etzkowitz, 2008: 13 -16). The interaction among universities, industries and governments requires them to play their traditional role and makes them appear in various combinations in order to stimulate the organization creativity. The fourth model involves civil society (Carayannis and Campbell, $2012: 13$ ), or community (Kolehmainen, et.al, 2015). 


\section{Institutional KBE: Innovation System}

Innovation system helps us understand the factors that shape innovation processes to the extent of growth related city problem solving (Johnson, 2008). Innovation system is about products and processes. Product innovation is subjected to new and better products, whether goods and/or services. Process innovation is a new way of producing goods and services using technology and/ or organization. The system innovation is the determinant of the innovation process. The development, deployment and usage of innovation are affected by economic, social, political, organizational, institutional and other factors. But the main components of innovation are the organization and institution (Edquist in Fagerberg, Movery and Nelson, 2005:182).

National Innovation System, known as Sistem Inovasi Nasional (SIN), has three (3) tiers: national, regional and sectoral. Sectoral Innovation System (Sistem Inovasi Sektoral/ SIS) is a collection of new as well as established products for special use completed with a set of agents who conduct market and nonmarket interactions for the creation, production and sale. SIN policies can be deployed to the local and regional levels, including city and region - based KBE development through the Regional Innovation System (SIR) (Regional Innovation System/SIR) (Pike, RodriguezPose and Tomaney, 2006: 97). SIR though still a relatively new concept and theoretically derived from economic geography scaling regional economic processes is a cluster-based regional development (OECD, 2007: 26-27). The latest theory emphasizes the systemic and evolutionary approach to innovation and learning (Uyarra, 2010: 117).

\section{Learning Regions}

An array of references contributed to a better understanding of the learning regions. In a simple sentence it can be concluded that learning comes from regional learning, clusters and networks, as well as institutional innovation. Region highlights the learning process of learning and spatial dimensions of the process. Clusters and networks draw attention to how the learning process is

Figure 1. The Anatomy of Learning Region.

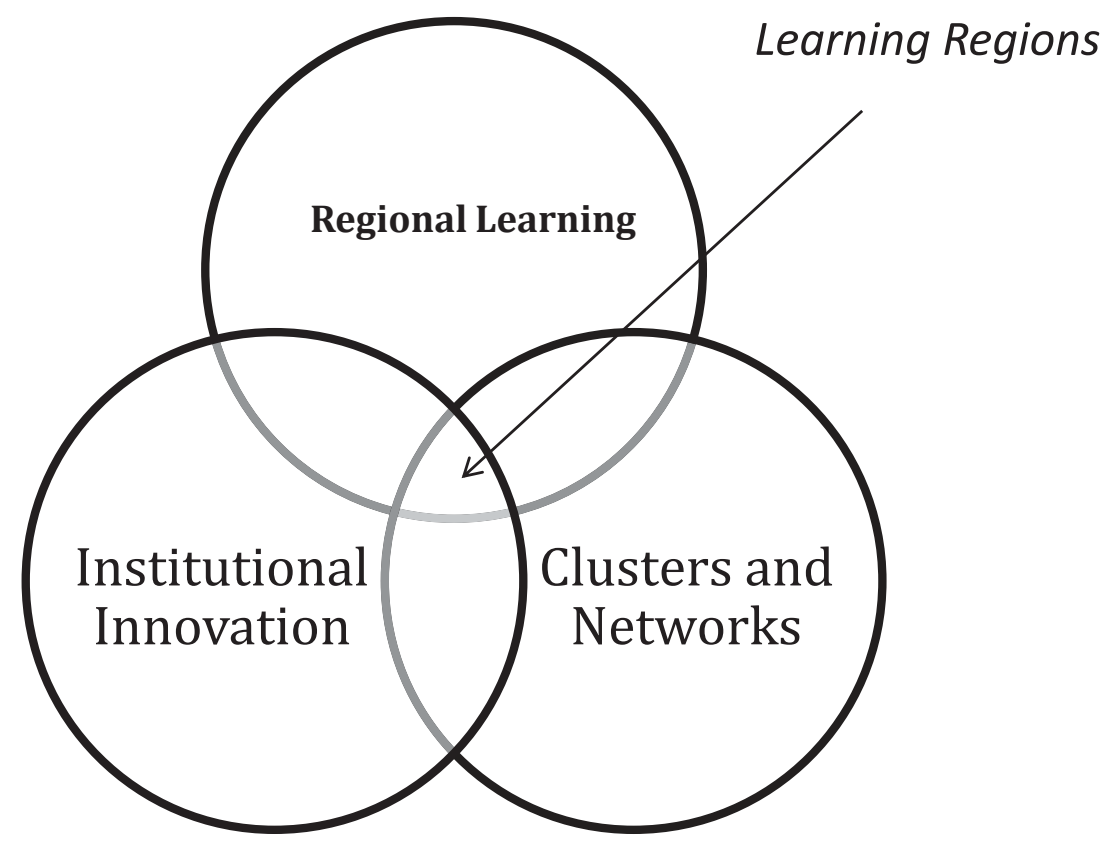

Souce: Rutten dan Boekema (2007: 5) 
organized. While institutional innovation refers to the invisible infrastructures (tangible) as well as intangible that supports learning and innovation. These three (3) concepts are overlaping but as regional learning takes place in the regional networks and supported by regional institutional innovation, we can discuss about learning regions further (Rutten and Bokema, 2007: 4).

Past researches related to technological innovation and knowledge commercialization indicate the positive role of knowledge or learning regions, also referred to regional innovation (regional innovation system) along with a cluster of high - tech, taking the role of driving forces in technological innovation (Technology Innovation Poles / TIP) in technology diffusion pursuit (Cooke et al., 1998) which has several key infrastructures such as the knowledge sector (research industries, research universities and $R \& D$ ), business sector (technology-based companies, cluster technologies, industrial parks, science parks and incubators) and public sector (city and county, state and federal government) (Corona, Doutraux and Mian, 2006: 4). Learning regions strongly associated with learning because of spatial proximity and tacit knowledge. In other words, learning regions are SIR strategies with a set of actors regional innovation interconnected, be it politicians, policy makers, chambers of commerce, trade organizations, higher education institutions, companies, research institutions and public companies which are flexibly connected (Hassink and Klaerding 2011: 141-142).

According to Isaksen (2001: 104), there are four (4) concepts derived from learning region which are region, knowledge, learning and innovation and institutional 'of regional clusters, regional innovation networks, regional innovation systems and learning regions. Then learning regions can be defined as "... Increased cooperation organized on a set of broad civic organizations and public authorities are attached to the social and regional structures". Learning regions provide a series of interconnecting infrastructure to facilitate the flow of knowledge, ideas and learning. Region has a set of basic materials in a system production consisting of manufacturing, human, physical and communications as well as industrial infrastructures and governance system (Florida, 2007: 64). one of the most important work derived from Richard Florida (1995) who was considered to be the scholar who popularized learning region concept and term. Others are Michael Storper (1993), Bjorn Asheim (1996) and Kevin Morgan (1997) (in Rutten and Boekema, 2007).

\section{Collaborative Governance}

Collaborative governance term were coined by Powell (1990) redressing market organization mechanisms, hierarchy and networks; Jessop (2002) concerning the exchange mechanism, command and dialogue; and Kooiman (1993; 2003) with the implementation of its own and the organization of joint. The mechanism of collaboration is to be a model of governance of cross-border administration at regional /local level. Triple helix actors are accommodated in terms of space and administration by city governments, overcoming collaborative obstacles and barriers.

Collaboration management is defined as "... a concept that describes the process of facilitation and operation in the implementation of multiorganisasi to solve problems that can not be solved, or not easy to solve, by one organization" (Agranoff and McGuire, 2003; Emerson, Nabatchi, and Balogh (2011) ; Senge (2008). While the type of activity and collaboration activities involving many parties (Agranof, 2000: 281) can be seen in the table 1.

According to New Regionalism, regions need to be independent in supporting learning and innovation at the local level. New Regionalism can be embedded in the concept of economic associations, learning 
Table 1.

Type of Activity and Collaboration Activities

\begin{tabular}{cl}
\hline \multicolumn{1}{c}{ Type of Activity } & \multicolumn{1}{c}{ Collaboration Activities } \\
\hline $\begin{array}{l}\text { Creating policies } \\
\text { and strategies }\end{array}$ & $\begin{array}{l}\text { Formal policy partnership; joint } \\
\text { policy-making; policy-making } \\
\text { favor } \\
\text { Resource exchange }\end{array}$ \\
& $\begin{array}{l}\text { Consolid ated policy efforts; } \\
\text { financial resources; combined } \\
\text { financial incentives } \\
\text { Contracting services; project } \\
\text { partnership; technical support }\end{array}$ \\
\hline Joint project & \multicolumn{1}{c}{ Organization } \\
\hline Organization & $\begin{array}{l}\text { Country; City; Special district } \\
\text { government } \\
\text { Chamber of Commerce/ } \\
\text { Associations; Foundation: } \\
\text { Private }\end{array}$ \\
$\begin{array}{l}\text { Utilities } \\
\text { Neighborhood associations; public } \\
\text { and private partnerships; industry } \\
\text { association }\end{array}$ \\
\hline
\end{tabular}

Source: Research results

regions, regional competitiveness and Regional Innovation Systems (SIR). New Regionalism holds perspectives that knowledge is an important input for economic growth (McCall, 2013: 79-80). Based on Etzkowitz and Klofsten (2005) research, there are four phases regions related to innovation - based KBE regional development i.e. (1) initial phase; (2) implementation phase; (3) consolidation phase; and (4) renewal phase. As a regional development model based on innovation, learning and exchanged regions are often equated with SIR, clusters of knowledge, innovation poles, and triple helix. Combining various concepts above, governing learning regions in the Jabodetabekjur urban region defined as follows: "Construction urban region involving knowledge - based economy in which exist triple helix horizontal collaboration in the form of policy making and strategies, exchange resources and project - based work". The conceptual model was developed from Corona, Doutriux, and Mian (2006) stages into an operational model involving knowledge, business and public sector. All of which contains regional actors, contexts and process innovation and research enablers.

\section{Research Methods}

This research used mixed methods approach using mixed model that combines both quantitative and qualitative data within and between the phases of research (Johnson and Onwuegbuuzie, 2004, $19-22$ ). The mixed model is applied with the emphasis on qualitative approach supplemented with quantitative approach. Both approaches are conducted mainly in the analysis and interpretation of data. The nature of this research is descriptive - explorative for its purpose are explaining how to construct the governance of collaborative development in Bogor, Depok and South Tangerang in reference with and/or modify existing theoretical framework.

Qualitative data are the main ingredient and were collected by using interviews and desk study. Interviews were conducted by means of semi - structured while secondary data were collected and categorized as archival records (archival records) in the form of text, tables and images. Both qualitative and quantitative data are processed further using thematic analysis technique and descriptive statistics respectively. The report writing process is part of the analysis since it was conducted in iterative way. Thematic analysis was performed with a hybrid approach, combining the deductive and inductive analysis (Fereday and Muir-Cochrane, 2006). The research process is described in the following figure.

\section{Findings and Analysis \\ Why Not Learning Regions?}

The establishment of learning regions in Jabodetabekjur has some obstacles. Firstly, Jabodetabekjur is indeed a fragmented region. Secondly, regulations are not supporting one another to the point of contradictory. Thirdly, failures of existing institution (Badan Kerja 
Figure 2.

Research Workflow

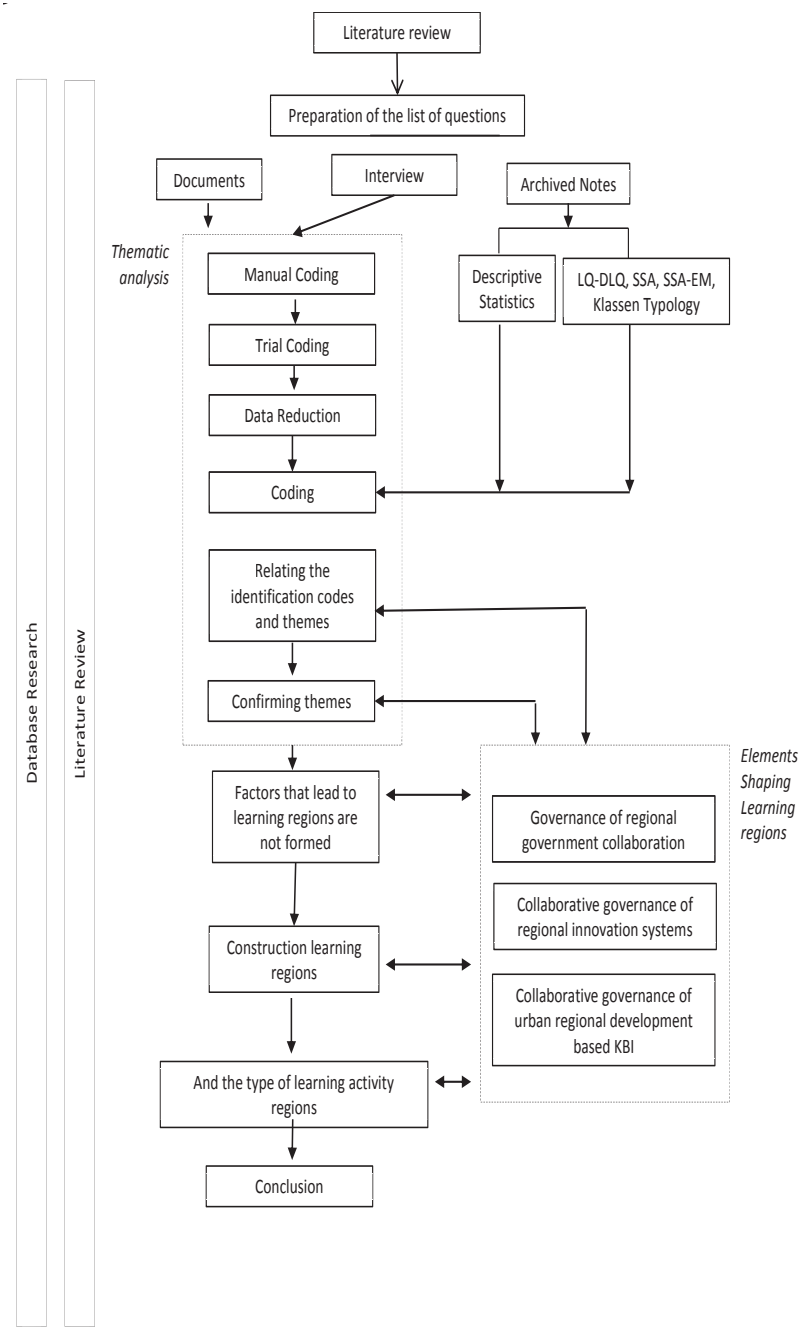

Source: Research results

Sama Provinsi-BKSP). Fourthly, unalignment of urban development strategies. Fifthly, the failure of national and regional institutional innovation. And sixthly, KBE's lost momentum. Jabodetabekjur as a fragmented region led to the tendency of the respective governments only to take care of their own areas and left the joint projects neglected. The failure in term of deliverables by BKSP aggravated the condition. Moreover, the economic development based on innovation through MP3EI program also has no clear outcome. The research center (Puspiptek) revitalization should have positive impacts to encourage the learning region but the local government have not built local innovation intitution such as Local Innovation System (Sistem Inovasi Daerah/SIDA).

\section{Potentials for Learning Regions in Bogor, Depok and South Tangerang}

Bogor, Depok and South Tangerang have potentials to become learning regions as shown on their trajectory of urban, industrial and economic development, infrastructure, science and research as well as development planning and the vision of the leader respectively. These potentials can also be seen through indicators such as HR and ICT infrastructures as well as actors, namely the helix involved, such as municipalities, universities and research institutes, as well as businesses and industries as summarized in the table 2 .

From the regulatory aspect, learning regions construction may have the priviledges due to: (a) Regional Autonomy as stipulated in 23/2014 Act; (b) National Spatial Planning in 26/2007 Act related to Jabodetabekjur urban and spatial planning, particularly ecoregion - based zoning arrangements in support of 54/2008 Presidential Decree; (C) National Development Strategies in 25/2004 Act which directs cities and regions development; (d) 17/2007 Act on Science and Technology; (e) Preparation of Local Innovation System (Sistem Inovasi Daerah/SIDA) in joint decree between Ministry of Internal Affairs and Ministry of Higher Education, Research and Technology).

In the future, urban region governance using collaborative learning network must foresee the physical condition the cities/ regions concerned. Location is a given aspect and plays a determining role and influences policies in region - based development. Therefore considering the cities (Depok, Bogor, South Tangerang) by zoning them altogether in the first place in Jabodetabekjur urban region becomes important. Based on zoning in 54/2008 Decree, these cities are in the 
Table 2.

Elements Forming Learning Regions in Bogor, Depok and

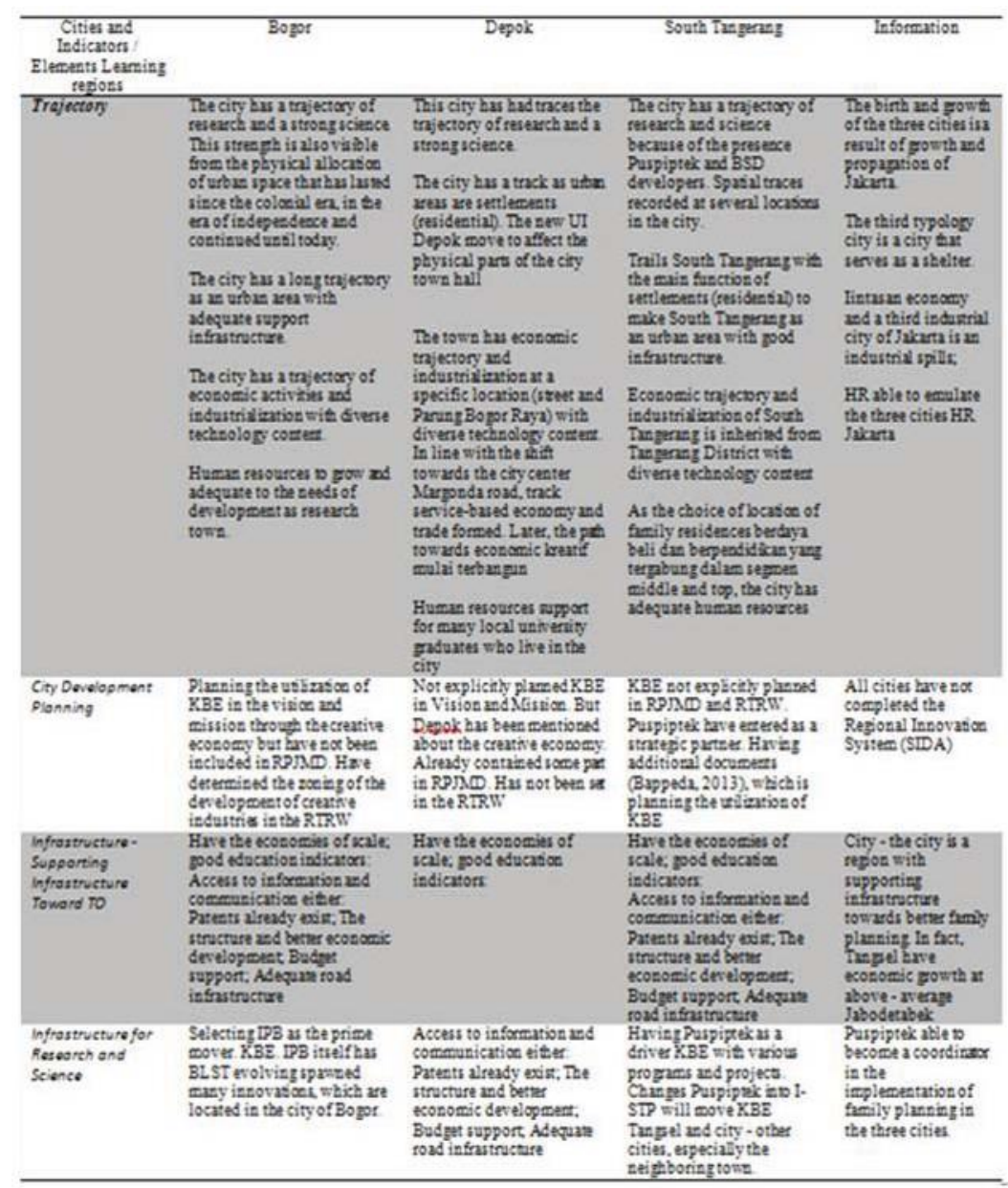

Source: Research results

zone III and zone IV. Zone III is region with considerable height above sealevel, slopes for drainage, not prone to flooding, considerable ground water, not good for agriculture but suitable for building construction. Zone III is conveniently located in Depok and South Tangerang. Based on this, both Depok and South Tangerang are suitable for large - scale research and manufacturing. Bogor is in Zone IV, a region with large slopes that does not require special drainages, flood free, limited water and good for both agriculture and construction. Bogor is in line with the need for agro - industrial innovation, as well as food and beverage production. Therefore, the presence of universities such as Bogor
Agricultural Institute (Institut Pertanian Bogor/IPB) through Bogor Life Science and Technology (BLST) is pertinent.

\section{Implementation of a Learning Region in Jabodetabekjur}

Implementation of Jabodetabekjur urban region as a learning region is inclusive to both local and regional governance. Economic growth requires implementation/re-scaling region to avoid fragmentation in governance, economic and social aspects as described in Table 03. 23/2014 Act is a strong basic for Jabodetabekjur urban learning region supplemented by 25/2004 Act and 17/2007 Act. The approach in 23/2014 Act is a public choice 
Table 3.

Governance and Regional Administration Approach in Implementating Learning Urban Region

\begin{tabular}{cll}
\hline $\begin{array}{c}\text { Governance } \\
\text { Administration }\end{array}$ & Network collaboration from shared governance and network governance \\
\hline Megional Governance & Jabodetabekjur as urban region \\
& $\begin{array}{l}\text { New Regionalism } \\
\text { Polisentrism }\end{array}$ & $\begin{array}{l}\text { Area - based in ecological, economic and social region } \\
\text { provisional), leadership facilitation. All stages of the learning }\end{array}$ \\
& Urban region construction with many centers perspective \\
\hline
\end{tabular}

Source: Research results

one while 26/2007 Act used a consolidated approach since national and local government were encouraged to form a coordinating organisation for Jabodetabekjur development (BKSP). Sadly, BKSP is not as effective that a need for a change in governing the region (i.e. collaboration network) is pertinent.

Collaboration networks is a necessity in constructing a learning regions activities since each element (local government, industries and universities/research institutes) has not optimizing their potentials and interactions due to their own degree of independence. The interaction is partially between one or two elements but not as a whole.

Based on the table, here are stages and collaboration model of learning region involving Bogor, Depok and South Tangerang. Triple helix collaborative learning in these cities blong to Jabodetabekjur urban area should follow these stages/ steps/procedures as mentioned.

1. Starting Stages. The initial conditions encouraging collaboration in Jabodetabekjur involving troubleshooting. Initiation is facilitated through the stages of cities' leaders - namely the mayors who shared $\mathrm{KBE}$ vision and strategic development.

2. Designing Stages. Providing the context of a collaboration along with the description of incentives and constraints as well as direction and purpose. Participant assessments, direction, purpose, process, implementation and results are essential. It starts with an opening meeting between regional government and universities and/ or research centers. For example, Depok local government initiates a meeting with University of Indonesia discussing KBE; as well as Bogor with Bogor Agricultural Institute; and South Tangerang with Center for Science and Technology Development (Puspiptek).

3. Implementation Stages. Based on the joint draft agreed by the triple helix actors including types, activities and project collaboration, it states agreed short term outcomes to be their quick wins.

4. Leadership Facilitation. This step is a necessity from the start. Bogor, Depok and South Tangerang mayors declare their willingness to initiate and facilitate the whole stage. It was considered essential in encouraging "learning" (Senge) and "listening" (Scharmer).

5. Interim Results. Final or interim results are important for the participants to see immediate positive impact on their collaborating activities. The actors involved should determine their targets before continuing to the next phase.

6. Learning Stages. All stages are an ongoing cycle designed to emerge novelties among helices interaction. The cyclical nature of the process allows outputs from previous phase to be the input for the next. This circular process ensures the sustainability of collaborating activities as described below. 
Figure 3.

The Classification of Jabodetabek Urban Region

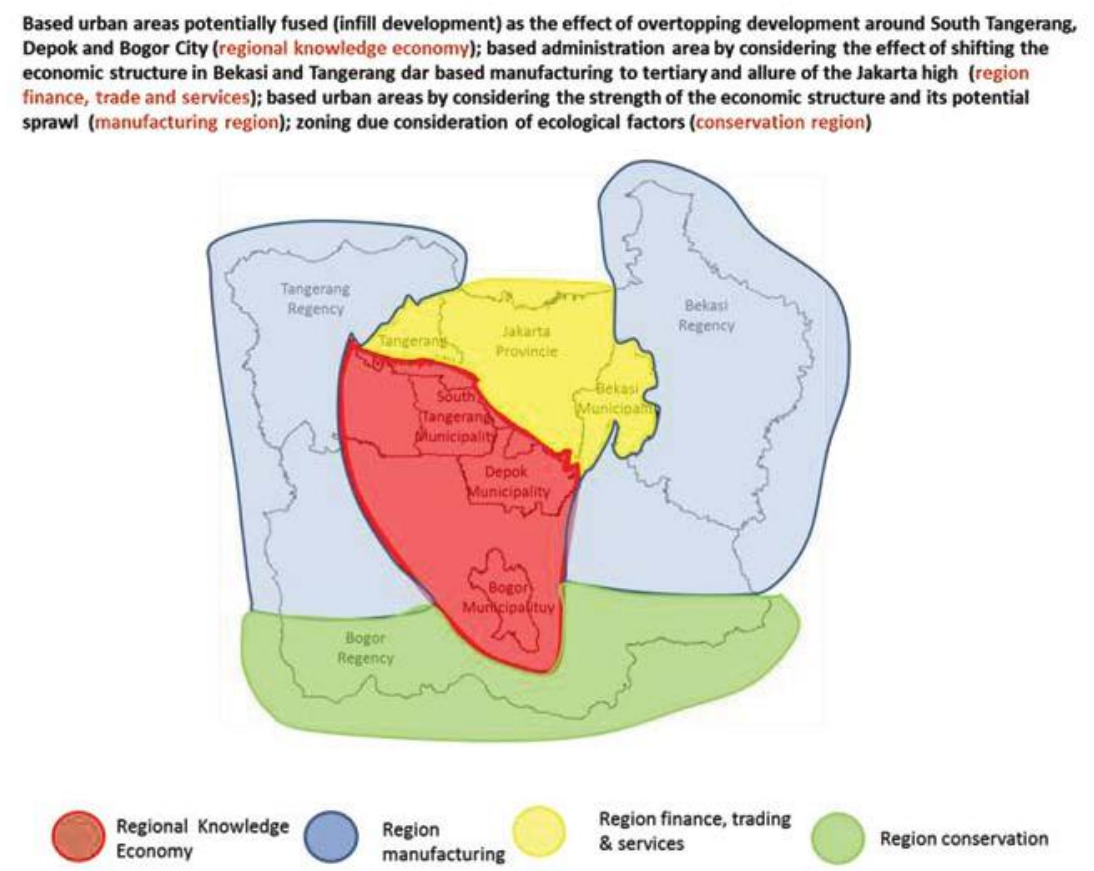

Source: Research Results

\section{New Regionalism}

Regional governance using New Regionalism approach to get out of the "trap" set by market hierarchy approach. New Regionalism leave some rooms for manuevres in building collaboration for all actors, private sector and/or public sector, in Jabodetabekjur urban region. Currently, Jabodetabekjur urban region was stucked on Jakarta's monocentrism. The cities growth in the region, including Bogor, Depok and South Tangerang was dictated by Jakarta as a capital city. Jabodetabekjur as an ecological region may refer to $54 / 2008$ Presidential Decree which divided it into 5 (five) zones ignoring administrative regions, economically and socially.

\section{Complex networks}

Complex networks approach in governing emphasis on governance without the need to create government (governance without government) as likely to be found in consolidated and many levels approach. The approach is aimed to manage the "excessive freedom" impact of public choice approach. A network supports a number of governments independently and voluntarily establish cooperation in various forms.

The helices in Bogor, Depok and South Tangerang can be desribed in a horizontal form complex networks. Overlaps in interactions may not be a duplication as long as it has a different purposes. Complexity is chosen to maximize choice and control. Thus, the region's comprehensive governance can be done organically based on local preferences. Complex network is capable of overcoming difficulties and instability due to incompleteness of certain functions among stakeholders.

By doing so, the networks open many possibilities for interaction and learning relationships that can occur in an within and or among helices in a different cities and can also be grouped by function (sectoral) (Table 4).

Interactions and relationships based on helical member in the administration area, acroos the administration area and functional similarity may open up new possibilities in 
Table 4.

Possible Interactions and Relationships in Learning Helical Regions i.e: Internal Area of Administration, Interregional Administration, and Function

\begin{tabular}{|c|c|c|c|}
\hline $\begin{array}{l}\text { Helix Interactions and } \\
\text { Relationships }\end{array}$ & $\begin{array}{c}\text { In the (inter) regional } \\
\text { administration }\end{array}$ & $\begin{array}{l}\text { Outside of (inter) regional } \\
\text { Administration }\end{array}$ & $\begin{array}{l}\text { One group with the } \\
\text { same functionality }\end{array}$ \\
\hline Bogor city & IPB & $\begin{array}{l}\text { Depok \& Tangsel; } \\
\text { UI \& Puspiptek; } \\
\text { BSD; } \\
\text { Creative Community Depok }\end{array}$ & Depok City \& Tangsel \\
\hline Depok city & UI Creative Communities & $\begin{array}{l}\text { Bogor \& Tangsel; } \\
\text { IPB \& Puspiptek; } \\
\text { BSD }\end{array}$ & Bogor City \& Tangsel \\
\hline Tangsel & Puspiptek to BSD & $\begin{array}{l}\text { Bogor and Depok; } \\
\text { UI \& IPB; } \\
\text { Creative Community Depok }\end{array}$ & Bogor City \& Tangsel \\
\hline IPB (BLST) & Bogor city & $\begin{array}{l}\text { Depok \& Tangsel; } \\
\text { UI \& Puspiptek; Creative } \\
\text { Community Depok }\end{array}$ & UI \& Puspiptek \\
\hline UI (Business Incubator) & $\begin{array}{l}\text { Depok city \& Creative } \\
\text { Communities }\end{array}$ & $\begin{array}{l}\text { Bogor \& Tangsel; } \\
\text { IPB \& Puspiptek; BSD }\end{array}$ & IPB \& Puspiptek \\
\hline $\begin{array}{l}\text { Community Creative } \\
\text { Industries Depok }\end{array}$ & Depok city \& UI & $\begin{array}{l}\text { Bogor \& Tangsel; } \\
\text { IPB \& Puspiptek; BSD }\end{array}$ & BSD \\
\hline Puspiptek & Tangsel \& BSD & $\begin{array}{l}\text { Bogor and Depok; } \\
\text { UI \& IPB; Creative } \\
\text { Community Depok }\end{array}$ & IPB \& UI \\
\hline BSD & Tangsel \& Puspiptek & $\begin{array}{l}\text { Depok and Bogor; } \\
\text { IPB and UI; Creative } \\
\text { Community Depok }\end{array}$ & $\begin{array}{l}\text { Creative Community } \\
\text { Depok }\end{array}$ \\
\hline
\end{tabular}

Source: Research results

collaboration. Its effectiveness was maintained with the accordance of learning region purpose as well as cooperation based on type and collaborating activities (e.g. policy making, resource exchange, and joint projects). The basis of this framework relies on supporting data of each helix engaging in collaboration type and activities.

Based on New Regionalism, polycentrism and complex networks can lead to space administration and organization in Jabodetabekjur urban region (esp. Bogor, Depok and South Tangerang) as follow.

\section{Bogor - Depok - South Tangerang Learning Collaboration Organisation}

Based on typologies, learning region come up with the local development agencies (namely Regional Development Agency/RDA) encouraging employment, entrepreneurship and innovation process (Mountford, 2009).
Table 5. Governance in Jabodetabekjur Urban Regions in Accordance with Collaboration and Learning Regions in Bogor, Depok and South Tangerang Regional Collaborative Urban Governance Jabodetabekjur

Key initiatives Region-based urban development (ecological, economic, political / administrative and social)

Type Region Polisentrisme

Institutional Decentralized Unitary State with wide regional autonomy - the extent of which open opportunities for cooperation between regions and between sectors of administration

Scale Region urban Jabodetabekjur

Establishment of learning regions

key initiatives Urban economic development based KBE

Type Region Learning regions (polycentric) Institutional collaboration networks Scale Three Cities (Bogor, Depok, Tangsel)

Source: Research result 
Table 6.

Organizational Design of Learning Organizers in Bogor, Depok and South Tangerang Learning Regions

\begin{tabular}{ll}
\hline \multicolumn{2}{c}{ Regional collaborative urban governance } \\
Jabodetabekjur
\end{tabular}

Source: Research results

Local development agencies related to economic development based on $\mathrm{KBE}$ learning regions in Bogor, Depok and South Tangerang fall into the categories although they face different context or circumstances. The RDA requires a form of organization that is in line with the problems, strategic issues, approaches and of course the organization design. Governance of the network has certain characteristics such as structure, number of members, decision making, advantages/disadvantages and problems involving elements of the helix in these cities learning regions. Those characteristics are:

The organisation design consists of structure, number of members, decision making process, costs and benefits as well as strategic issues. So far, RDA is designed in line with the needs of collaborative learning regions. The model is in accordance with the third collaboration in which emphasizes selfgovernance network with modifications to the learning needs of the three cities region as drafted below.

\section{Collaborative Learning Type and Activities Construction in Bogor, Depok and South Tangerang \\ Collaborative Policy Development and Strategy}

Policymaking and strategic planning offered by Agranoff and McGuire contained policy partnerships, joint policies and assistance in implementing policy which cannot absolutely work in the context of learning regions. The findings are the collaboration construction and strategic policy-making has to be in line with the development of each city, governance approach, potentials as well as infrastructures

Table 7.

Hosting Organization Model of Collaborative Learning in Three cities region

\begin{tabular}{|c|c|}
\hline Design Features & Information \\
\hline Structure & $\begin{array}{l}\text { There are no structures / Special administrative cooperation / collaboration of all elements of the } \\
\text { triple helix in the three cities of Bogor, Depok and South Tangerang. The participants have the } \\
\text { administration of each }\end{array}$ \\
\hline $\begin{array}{l}\text { Number of } \\
\text { Members }\end{array}$ & $\begin{array}{l}\text { The number of members of a couple. The total area of the administration of the urban region } \\
\text { in Jabodetabekjur consisting of } 9 \text { (nine) autonomous administrative region. Especially for the } \\
\text { establishment of learning regions only three (some) pemerintrahan administration (the city of } \\
\text { Bogor, Depok and South Tangerang). Coupled with two universities (UI and IPB), and one research } \\
\text { institute (Puspiptek). Among some of the industry / business / community terlbat, only the BSD } \\
\text { which has a strong influence. While the creative industries community Depok city has not had a } \\
\text { strong influence. }\end{array}$ \\
\hline $\begin{array}{l}\text { Decision } \\
\text { Making }\end{array}$ & $\begin{array}{l}\text { Decentralized decision-making or independently depending on each helix because each element } \\
\text { have the independence in decision-making. }\end{array}$ \\
\hline Excellence & $\begin{array}{l}\text { All stakeholders of the elements - elements of the triple helix aware, willing and have the desire } \\
\text { to do a collaboration. The three cities on different scales have the infrastructure KBE }\end{array}$ \\
\hline Problem & $\begin{array}{l}\text { Yet has a history of strong collaboration, administration and operation of the divided region - broke, } \\
\text { domination Jakarta, suspicions of the past and sectoral excessive ego }\end{array}$ \\
\hline
\end{tabular}

Source: Research results 
Table 8.

Collaborative Activity in Policy Making and Strategy: Themes, Vision and Mission and Principles of Engagement

\begin{tabular}{|c|c|}
\hline Activity & Explanation \\
\hline $\begin{array}{l}\text { Determination } \\
\text { of the themes } \\
\text { development KBE }\end{array}$ & $\begin{array}{l}\text { Themes choice include overall theme, type and activity of collaboration not only collaborative } \\
\text { policy-making and strategy (determination of shared vision and mission; the establishment of } \\
\text { the principle - the principle of collaboration; structuring collaborative network (organization)), } \\
\text { but covers the exchange of resources (resource exchange antarheliks and intraheliks ) and } \\
\text { joint projects (promotion and implementation of SIDA; a joint project (1) incubation cluster } \\
\text { development and cluster promotion of products and services KBE three cities. }\end{array}$ \\
\hline $\begin{array}{l}\text { Determination of } \\
\text { shared vision and } \\
\text { mission }\end{array}$ & $\begin{array}{l}\text { Vision: prosperity, justice, sustainability, innovation-technology-Haki, competitiveness; } \\
\text { Mission: to encourage collaboration between the helices in learning regions that create learning } \\
\text { antarheliks and intraheliks; raises and construct activities and interaction of the organization / } \\
\text { organization units collaborators learning regions; determine the type of organization (for profit } \\
\text { or non-profit?). }\end{array}$ \\
\hline $\begin{array}{l}\text { Determination } \\
\text { of principles } \\
\text { collaboration }\end{array}$ & $\begin{array}{l}\text { Principles of engagement: autonomous policymaking by laws - laws; have administrative } \\
\text { independence and space as laws; has authority in matters of compulsory and choice affairs; } \\
\text { can cooperate with other local authorities or with third parties; have the right to regulate the } \\
\text { operation of spatial regions each with reference to the rules on it; non-governmental stakeholders } \\
\text { helices have the independence sectorally based on state laws } \\
\text { Motivation together: mutual trust; mutual understanding; have internal legitimacy; a } \\
\text { commitment } \\
\text { Capacity: setup / administration; procedures / institutional; leadership; availability of knowledge; } \\
\text { availability of resources }\end{array}$ \\
\hline
\end{tabular}

Source: Research results

adapted by KBE vision and mission of KBE and stages of development. Policymaking and or strategic planning concern on stages from starting to designing collaboration which are: (1) KBE themes choices; (2) shared vision and mission; and (3) collaboration principles.

\section{Resources Exchange Collaboration}

Resource exchange collaboration can be done based on the gap analysis of the helices elements. Ideally, the gap could be addressed by other helical elements. Thus each helix can maximize their potentials to benefit KBE as summarized in Table 9.

\section{Joint Project Collaboration}

Collaborative planning in policy making and strategy can cover the gaps of collaborative activity especially in resource exchange. Both activities are able to demonstrate the collaborative joint projects in Bogor, Depok and South Tangerang. Several joint projects can be undertaken in line with the learning region design aimed to create short - term successes (quick wins). Quick wins are expected to strengthen helical awareness and participation in collaboration since they are positive results and show immediate benefits. At the beginning stage, the interaction among helices is not yet to be named a collaboration. But in order to gain quick wins, there are several forms of collaboration that can be addressed.

1. Collaboration in technology. In the context of these cities collaboration, a learning region can implemented between food and beverage industries with Bogor Life Science and Technology (BLST).

2. Collaboration in products launching. This collaboration can be done usiang BLST existing product brand such as Botany and expand its market. Jabodetabekjur with its almost 30 million inhabitants is a huge potential market. South Tangerang with its fastest economic growth is more than able to host the project.

3. Collaboration between products. It can occur between BLST whose developing medicinal products (e.g. drugs and supplement) and 
Table 9.

Resource Gaps and Exchange Helices in Bogor, Depok and South Tangerang

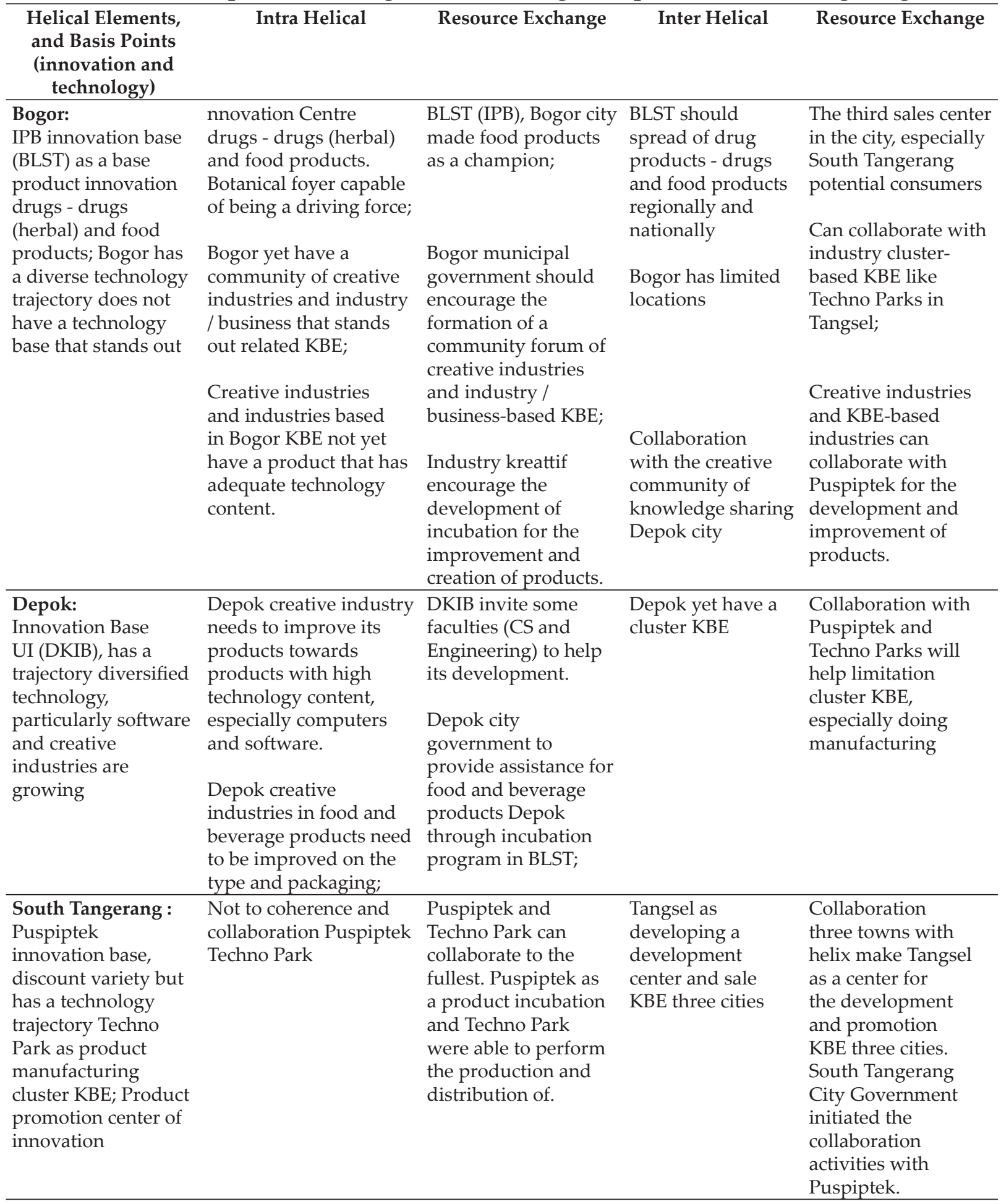

Source: Research Results 
Table 10.

Collaboration: Activities, Shapes and Location.

\begin{tabular}{lll}
\hline \multicolumn{1}{c}{ Activity } & \multicolumn{1}{c}{ Form } & \multicolumn{1}{c}{ Locations } \\
\hline Incubator together & $\begin{array}{l}\text { Innovation and incubation center of food } \\
\text { products and beverages }\end{array}$ & Bogor City, IPB-BLST \\
& Innovation centers and software development & Depok City, UI-DKIB \\
Incubator together & Product Innovation Promotion Center & South Tangerang City \\
\hline
\end{tabular}

Source: Research Results

Depok and South Tangerang as business incubators.

Some examples above are subjected to be quick wins for collaboration activities. But in the context of RDA, two (2) activities can be followed up. They are: (1) an innovation center as business incubators; and (2) product innovation promotion centers.

\section{Conclusion}

This study addresses three research questions: (1) the reasons why learning Jabodetabekjur urban regions has not been established yet; (2) how to construct learning regions in the urban region Jabodetabekjur; (3) and how to construct the type and the helical collabortion activity in three cities. The finding that stands out is the initiation of the local government to build interaction per helix because it has authority to take a lot of action than other helices. Regional autonomy that had created a harmful fragmentation turned out to be reversed into excellence by optimizing collaborative governance. Learning regions with the governance of the collaboration also maximizes the authority obtained through regional autonomy that will differentiate the approach in organizing the static model and market. Initiation of the local government supports the role of local government, but with the volunteer spirit, which distinguishes it from a static model of the triple helix theory. This is an important finding in this study both academically and practically. In this study there are obstacles, particularly the lack of data, related to the
KBE. Therefore researchers need to explore more data in the future.

\section{References}

Asian Development Bank. (2014). Innovative Asia : Advancing The Knowledge-Based Economy. Country Case Studies for the People's Republic of China, India, Indonesia, and Kazakhstan. ADB: Manila.

Agranoff, Robert. (2000). Collaborative Policy Making And Administration: The Operational Demands Of Local Economic Development. Economic Development Quarterly, 14(3), pp. 378-391.

Agranoff, Robert and Michael McGuire. (2003). Collaborative Public Management: New Strategies for Local Goverments. Washington: Goerge Town University Press.

Blakely, Edward and Bradshaw, Ted K. (2002).

Planning Local Economic Development Theory and Practice. Thousand Oaks, London, New Delhi: Sage Publications.

Carayannis, Elias G. and Campbell, David F.J. (2012). Mode 3 Knowledge Production in Quadruple Helix Innovation System. New York: Springer.

Carvalho, Luis. (2013). Knowledge Locations In Cities Emergence And Development Dynamics. ERIM PhD Series In Research In Management, 274

Corona, Leonel, Doutriaux, Jerome dan Mian, Sarfraz A. (2006). Building Knowledge Regions in North America Emerging Technology Innovation Poles. Chetelham: Edward Elgar Publishing Limited. 
Etzkowitz, Henry. (2008). The Triple Helix University-Industry-Governmentt Innovation in Action. New York: New York and London Routledge.

Florida, Richard. (2006). Toward Learning Regions. Rutten. In Roel dan Frans Boekema (Eds.), The Leaning Region Foundation, State of the Art, Future. Chelteham, Uk: Edward Edgar Publishing Limited

Florida, Richard. (2005). Cities And The Creative Class. New York: New York and London Routledge.

Hamilton, David K. (2013). Measuring Effectiveness Of Regional Governing System: A Comparative Study Of City Regions In North America. Heildelberg: Springer.

Hassink, Robert and Klaerding, Claudia. (2011). Evolutionary Approach To Local And Regional Develompment Policy. In Pike, Andy, Rodriguez-Pose, Andres and Tomaney, John (Eds.), Hanbook Of Local And Regional Development. New York: New York and London Routledge.

Gustavsen, Bjorn, Nyhan, Barry, Ennals, Richard. (2007). Learning Together for Local Innovation: Promoting Learning Regions. Cedefop, Luxembourg: Office for Official Publications of the European Communities.

Jessop, Bob. (2002). The Future Of The Capitalist State. Cambridge: Polity Press.

Kooiman, Jan. (1993). Modern Governance New Government-Society Interactions. In Kooiman, Jan (Eds.), London: Sage Publications Ltd. . (1993). Governance And Governability: Using Complexity, Dynamics And Diversity. In Kooiman, Jan (Eds.), Modern Governance New Government-Society Interaction. London: Sage Publications Ltd. (2003). Governing As Governance. London: Sage Publications Ltd.

Martini, Lenny Et.all. (2012). Triple Helix Collaboration To Develop Economic Corridors As Knowledge Hub Indonesia.
Procedia-Social And Behavioral Sciences, 52(2012), pp.130-139.

McCann, Philip. (2001). Urban And Regional Economics. New York: Oxford University Press.

Milward, Brinton H. and Provan, Keith G. (2006). A Manager's Guide To Choosing And Using Collaborative Networks. Washington, DC: IBM Centre For The Business Of Government

Musterd, Sako and Murie, Alan. (Ed). (2010). Making Competitive Cities. In IBM Centre For The Business Of Government (Eds.). United Kingdom: Blackwell Publishing. OECD. (2013). Innovation In South East Asia. Paris, Paris: OECD Publishing. . (2007). Competitive Regional Clusters National Policy Approaches. Paris: OECD Publishing. . (2006). Competitive Cities In The Global Economy. Paris: OECD Publishing. (2005a). Building Competitive Regions Strategies And Governance. Paris: OECD Publishing. . (2005b). Building Competitive Regions Strategies And Governance. Paris: OECD Publishing.

. (2001). Cities And Regions In The New Learning Economy Paris: OECD Publishing. Pike, Andy, Rodriguez-Pose, AndresdanTomaney, John. (2006). Local And Regional Development. Routledge, Abingdon

Porter, Michael E. (1990). The Competitive Advantage Of Nations. London dan Basingtoke: The Macmillan Press.

Rainey, Hal. G. (2009). Understanding And Managing Public Organizations.San Francisco: Jossey-Bass.

Rutten, Roel and Bokema, Frans. (2007). The Learning Regions. Rutten, Roel dan Bokema, Frans. (Ed.). The Learning Regions Foundation, State Of Art, Future. Cheltenham, UK: Edward Elgar. 
Scharmer, Otto. (2007). Theory U: Leading From The Future As It Emerge. MA: Society for Organizational Learning, Cambridge.

Senge, Peter and kawan - kawan. (2008). The Necessary Revolution How Individual and Organizations Are Working Together to Create Sustainable World . New York: Doubleday.

Suh, Joonghae and Chen, Derek H.C. (2007). Korea as A Knowledge Economy Evolutionary Process and Lesson Learned. Washington DC: World Bank Institute.

Van den Berg, Leo, Van Winden, Willem. (2004). Cities in the Knowledge Economy: New Governance Challenges., Rotterdam: Euricur.

Van Winden, Willem, De Carvalho, Luis, Van Tuijl, Erwin, Van Haaren, Jeroen, dan Van Den Berg, Leo. (Ed.). (2010). Creating Knowledge Locations in Cities Innovation and Integration Challenges. Euricur Rotterdam: Routledge.

World Bank. (1999). Knowledge for Development. Washington DC: World Bank.

\section{Journals, Papers and Articles}

Agranoff, Robert and Michael McGuire. (1997). Multinetwork Management: Collaboration and the Hollow State in Local Economy Policy. Journal of Public Administration Research and Theory, 8(1), pp. 67-91.

Ansell, Chris and Gash, Alison. (2007). Collaborative Governance in Theory and Practice. Journal of Public Administration Research and Theory, 18(4), pp. 543-571.

Emerson, Kirk, Nabatchi, Tina dan Balogh, Stephen. (2011). An Integrative Framework for Collaborative Governance. Journal of Public Administration Research and Theory, 22(1), pp. 1-29.

Braun, V. and Clarke, V. (2006). Using Thematic Analysis in Psychology. Qualitative Research in Psychology, 3(2). pp. 77-101.

Cooke, Philip and Leydesdorff, Loet. (2006). Regional Development in the Knowledge-
Based Economy: The Construction of Advantage. Journal of Technology Transfer, 31(1), pp. 5-15.

Etzkowitz, Henry. (2002). The Triple Helix

Of University - Industry - Government Implication For Policy And Evaluation. Working Paper 2002-11. Institute for Studies Av Utbildning Och Forsknig

Etzkowitz, Henry. (2002). The Triple Helix Of University - Industry - Government Implication For Policy And Evaluation. Working Paper 2002-11. Institute for Studies Av Utbildning Och Forsknig

Etxkowitz, Henry and Leydesdorff, Loet. (2000).

The Dynamics Of Innovation: From National System And "Mode2" To A Triple Helix Of University-Industry-Government Relatiosn. Research Policy, 29(2000), pp. 109-123.

Etzkowitz, Henry and Klofsten, Magnus. (2005).

The Innovating Region: Toward a Theory of Knowledge-Based Regional Development. R\&D Management, 35(3), Pp. 243-255.

Fereday, J., \& Muir-Cochrane, E. (2006). Demonstrating Rigor Using Thematic Analysis: A Hybrid Approach of Inductive and Deductive Coding and Theme Development. International Journal of Qualitative Methods, 5(1), pp. 80-92.

Hudallah, Delik and Firman, Tommy. (2012). Beyond Property: Industrial Estate And Post-Suburban Transformation in Jakarta Metropolitan Region. Cities, 29(1), pp. 4048.

Irawati, Dessy and Rutten, Roel. (2011).

The Java Outomotive Industry: Between Keiretsu and Learning Region. Journal For Global Business Advancement, 4(3), pp. 208-223.

Isaksen, Arne. (2001). Building Regional Innovation System : Is Endogenous Industrial Development Economy Possible in Global Economy?. Canadian Journal of Regional Science, 24(1), pp. 101-120.

Johnson, Bjorn. (2008). Cities, System of Innovation and Economic Development. 
Innovation: Management, Policy, \& Practice, 10(2-3), Pp.146-155.

Johnson, Burke and Onwuegbuuzie, Anthony J. (2004). Mixed Method Research : A Research Paradigm Whose Time Has Come. Educational Research, 33(7), pp. 14-26.

Kolehmainen, Jari Et.all. (2015). Quadruple Helix, Innovation and Knowledge-Based Development: Lesson From Remote, Rural, and Less-Favoured Regions. Journal of Knowledge Economy, 7(1), pp.23-42.

Kubler, Daniel. (2012). Introduction: Metropolitanisation and Metropolitan Governance. European Political Science, 11(3), pp. 402-408.

LeSage Jr, Edward C. and Stefanick, Lorna. (2004). “New Regionalist Metropolitan Action: The Case Of The Alberta Capital Region Alliance". Dipresentasikan pada pertemuan Asosiasi Ilmu Pengetahuan Politik Kanada, Winnipeg, Juni 2004

McGuire, Michael, Agranoff, Robert and Silvia, Chris. (2010). Collaborative Public Management. Public Administration Review, 2010, ASPA

Powell, Walter W. (1990). Neither Market Nor Hierarchy: Networks Forms Of Organization. Research In Organization Behavior, 12, pp. 295-336.

Porter, Michael E. (2007). The Competitive Advantage Of Regions. Dipersiapkan untuk The Columbus Partnership Retreat John F. Kennedy School Of Governement

Supriyadi, Ery. (2012). Local Economic Development And Triple Helix: Lesson Learned From Role Of Universities In Higher Education Town Of Jatinangor, West Java. Procedia-Social And Behavioral Sciences, 52, pp. 299-306.
Yigitcanlar, Tan, Velibeyoglu, Korav dan Fernandez, Christina. (2008). Rising knowledge cities : the role of urban knowledge precincts. Journal of Knowledge Management, 12(5), pp. 8- 20.

\section{Thesis and Dissertation}

Purwaningrum, Farah. (2012). Knowledge Governance In An Industrial Cluster The Collaboration Between Academia-IndustryGovernment. Dissertation. Universitas Bonn

\section{Reports}

Mountford, Debra. (2009). Organising for Local Development: The Role of Local Development Agencies. Summary Report. Working Document. OECD LEED Programme.

\section{Regulations}

UU No 17 Tahun 2007 tentang RPJMN 20052025

UU No. 23 Tahun 2014 tentang Pemerintahan Daerah

UU No.32 Tahun 2004 tentang Pemerintahan Daerah

UU No. 26/2007 tentang Penataan Ruang

UU No. 25/2004 tentang Sistem Perencanaan dan Pembangunan Nasional

UU No. 18/2002 Sistem Nasional Penelitian, Pengembangan dan Penerapan Ilmu Pengtahuan dan Teknologi

Kementerian Riset dan Teknologi. (2014). Panduan Penguatan SIDa.

Keppres No 54 Tahun 2008 mengenai Penataan Ruang Kawasan Jakarta, Bogor, Depok, Tangerang, Bekasi, Puncak, Cianjur. 